\title{
CDKN2A Gene
}

National Cancer Institute

\section{Source}

National Cancer Institute. CDKN2A Gene. NCI Thesaurus. Code C18022.

This gene functions as a tumor suppressor and transcriptional regulator. 